\title{
Editorial
}

\section{The Origin of Facial Palsy in Multiple Sclerosis}

Arianna Di Stadio, MD, PhD ${ }^{*}$; Evanthia Bernitsas, MD²

'Department of Neurology, San Camillo Hospital IRCCS, Venice, Italy

${ }^{2}$ Multiple Sclerosis Center, Wayne State University School of Medicine, Detroit, MI, USA

"Corresponding author

Arianna Di Stadio, MD, PhD

Assistant Professor, Department of Neurology, San Camillo Hospital IRCCS, Venice, Italy; E-mail: ariannadistadio@hotmail.com

Article information

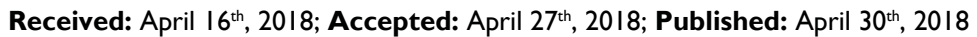

\section{Cite this article}

Di Stadio A, Bernitsas E. the origin of facial palsy in multiple sclerosis. Otolaryngol Open J. 2018; 4(I): el-e4. doi: 10.17/40/OTLOJ-4-e006

$\mathrm{M}$ ultiple Sclerosis (MS) is an autoimmune neurodegenerative disease that affects several people especially in North America and Canada. In 2013, 33 individuals over 100,000 were affected from MS; the estimated increase for 5 years of observation ranged from an average of 4.7 per 100,000 in high-income countries to just 0.04 per 100,000 in the low-income countries. ${ }^{1}$

Women are more affected than men (2.3-3.5:1), but in men, the disease is usually more aggressive and has a worse prognosis than in women. ${ }^{2}$

MS is a demyelinating disorder in which the immune system attacks the neural structures in the central nervous system (CNS) ${ }^{3}$; this mechanism is determined by a particular class of cellsMicroglia- thathave been identified as responsible of the degenerative process. These cells, that belong to the macrophage family, have the ability to move and they can easily migrate in different part of $\mathrm{CNS}^{4}$ and due to their two different phenotypes, an aggressive one, called M1, that induce neurodegeneration and, a protective phenotype (M2) that has neuroprotective ability ${ }^{3}$ they may be induce demyelination and regeneration in different phases of MS, as for example, in the relapsing and remitting disease.

In the active (relapsing) stage of MS, microglia M1 induces demyelination in the area of CNS where they currently are located. If the area interested is a motor one, the patient manifests movement disorders as stiffness or motor fatigue, in case of an attack in a sensory area the sensorial perception will be the affected one.

The facial pathway, that starts in the periphery with the terminal branch of the facial nerve and ends up to the M1 area of cortex (Figure 1), may be attacked by microglia and a demyelinating process that involves one or more areas of this pathway may be symptomatic as facial palsy (FP).

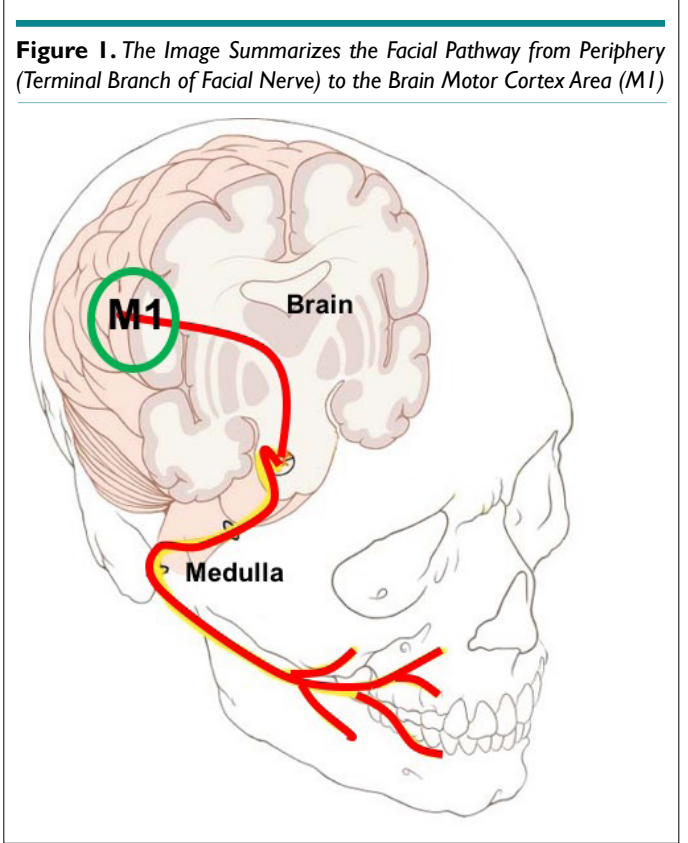

Authors report that around $7 \%$ of patients affected by MS experienced one episode of FP at least once in their life, but some controversies are still open about the origin of this symptom.

How many of these FPs are central and how many may arise from a peripheral involvement of facial nerve?

We reviewed the literature from 1997 to 2014 and we identified from a total of 16 articles, that most of the MS patients suffered from central facial involvement when they presented with a FP (Table 1).

Three authors, unfortunately, did not report details about the site of the lesions so we were not able to completely under- 


\begin{tabular}{|c|c|c|c|c|c|}
\hline Authors & Year & Study type & Sex & Facial & MRI results \\
\hline Saleh $^{7}$ & 2016 & Case Report & Man & yes Right side & $\begin{array}{l}\text { Three lesions in the supratentorial, periventricular region. Two on the right side, one on } \\
\text { the left (sizes between } 8-13 \mathrm{~mm} \text { ). In spine small lesion at the level of the right caudal } \\
\text { pons, inferior to the facial nucleus }\end{array}$ \\
\hline Jens ${ }^{8}$ & 2015 & Case Report & Woman & $\begin{array}{l}\text { yes Right side } \\
\text { started with } \\
\text { numbness }\end{array}$ & $\begin{array}{l}\text { Lesion in the floor of } 4^{\text {th }} \text { ventricle at the pons and two in the right cerebral white matter } \\
\text { and cerebellum }\end{array}$ \\
\hline Sarigul ${ }^{9}$ & 2014 & Case Report & Woman & yes Left side & Lesions in right parietal and left fronto-parietal areas \\
\hline Lassemi $^{10}$ & 2014 & Cross-Sectional & $\begin{array}{l}73 \% \text { women, } 27 \% \\
\text { men ( } 400 \text { patients) }\end{array}$ & I7\% of sample & Not available \\
\hline Danesh-Sani"I & 2013 & Prospective & $\begin{array}{l}32 \% \text { men, } 68 \% \\
\text { women }(500 \\
\text { patients) }\end{array}$ & $\begin{array}{l}\text { yes } 19 \% \text { of } \\
\text { subjects }\end{array}$ & Lesion in the brain \\
\hline Lee $^{12}$ & 2013 & Case Report & Man & yes Right side & Lesion in the midline of dorsal pons \\
\hline Renard ${ }^{13}$ & 2012 & Case Report & Woman & yes Left side & $\begin{array}{l}\text { Lesions in the left } \\
\text { pontine tegmentu }\end{array}$ \\
\hline Uzawa $^{14}$ & 2011 & Case Report & Woman & yes Left side & Lesion in the left facial colliculus \\
\hline Ivankovic $^{15}$ & 2011 & Case Report & Woman & yes Right side & $\begin{array}{l}\text { Lesions in the supra and infratentorial region of the brain (periventricular, corpus cal- } \\
\text { losum, pons, cerebellum }\end{array}$ \\
\hline $\operatorname{Lin}^{16}$ & 2010 & Case Report & Man & yes Left side & Lesion in the lateral walls of the lateral ventricles \\
\hline Soltanzadeh ${ }^{17}$ & 2008 & Prospective & 41 Women, 12 men & yes & Not available \\
\hline Kwon ${ }^{18}$ & 2008 & Case Report & Woman & $\begin{array}{l}\text { yes Right side } \\
\text { started with } \\
\text { numbness }\end{array}$ & Lesion in the right cerebellopontine angle involving the Roof Entry Zone (REZ) \\
\hline Zadro ${ }^{19}$ & 2008 & Retrospective & 18 not defined & yes not defined & $66 \%$ of the subject presented brain lesions \\
\hline Critchley ${ }^{20}$ & 2004 & Case Report & Man & yes Right side & Lesions diffused in the brain \\
\hline Thomke ${ }^{21}$ & 1997 & Prospective & 2 men, I woman & yes not defined & No identify cablevision in MRI \\
\hline Fukazawa $^{22}$ & 1997 & Prospective & $\begin{array}{l}25 \text { subjects (men vs. } \\
\text { women: I: } 2.7)\end{array}$ & yes not defined & $\begin{array}{l}\text { Lesions in the pontine tegmentum ipsilateral to the facial palsy ( } 21 \text { with multi nerve } \\
\text { involvement); no lesions in the two with pure facial palsy }\end{array}$ \\
\hline
\end{tabular}

stand the origin of the FP.

In two cases (a man and a woman) the authors reported vestibular and auditory symptoms associated with the onset of facial palsy, while another author reported a woman that showed only vertigo complicating his facial paralysis.

In only 1 case, as reported by Kwon et $\mathrm{al}^{18}$, the origin of facial palsy may be directly correlated with the presence of a lesion in the roof entry zone (REZ).

Overall, none of the authors reported cases of FP linkable with a peripheral demyelination process as for example an involvement of the facial nerve external to the stylus-mastoid foramen, where the nerve comes out from the fallopian canal.

It is also important to remember that a peripheral demyelination in MS patients is rarely described ${ }^{5}$ and the most of the authors believe that the motor disease observed in MS is related to the lesion in brain, pons, and medulla more than a peripheral involvement.

In case of MS-related vestibule-cochlear involvement, instead, a peripheral involvement of inner ear might happen ${ }^{4}$ in fact the presence of macrophages/microglia has been identified in patients affected from auto-immune diseases in human temporal bone study.

We are trying to understand the reason which, in presence of a MS-related facial palsy, the central lesion mimics a peripheral involvement presenting with a complete involvement of all facial muscles.

Is it possible the majority of the lesions are located in the medulla or, the lesion in the central pathway are associated with a peripheral involvement of facial nerve in its bone tract that is not visible in the magnetic resonance imaging (MRI)?

The particular anatomy of the facial pathway supports the hypothesis of the central involvement, in fact, both cerebral hemispheres (area of motor cortex with the posterior limb of internal capsule and the corticobulbar tract) are responsible for the movement of the frontalis muscle, while only the contralateral cortex innervates the lower motor neurons that drive the muscles under the frontalis. So, due to the wide diffusion of MS lesions in the brain, is very uncommon to observe the typical "central facial palsy" in those patients (Figure 2), while is more common to observe a "peripheral facial palsy".

The action of the microglia supports the concept of superior facial pathway involvement in the MS-related facial palsy, in fact, these cells (responsible of demyelization phenomena) are 


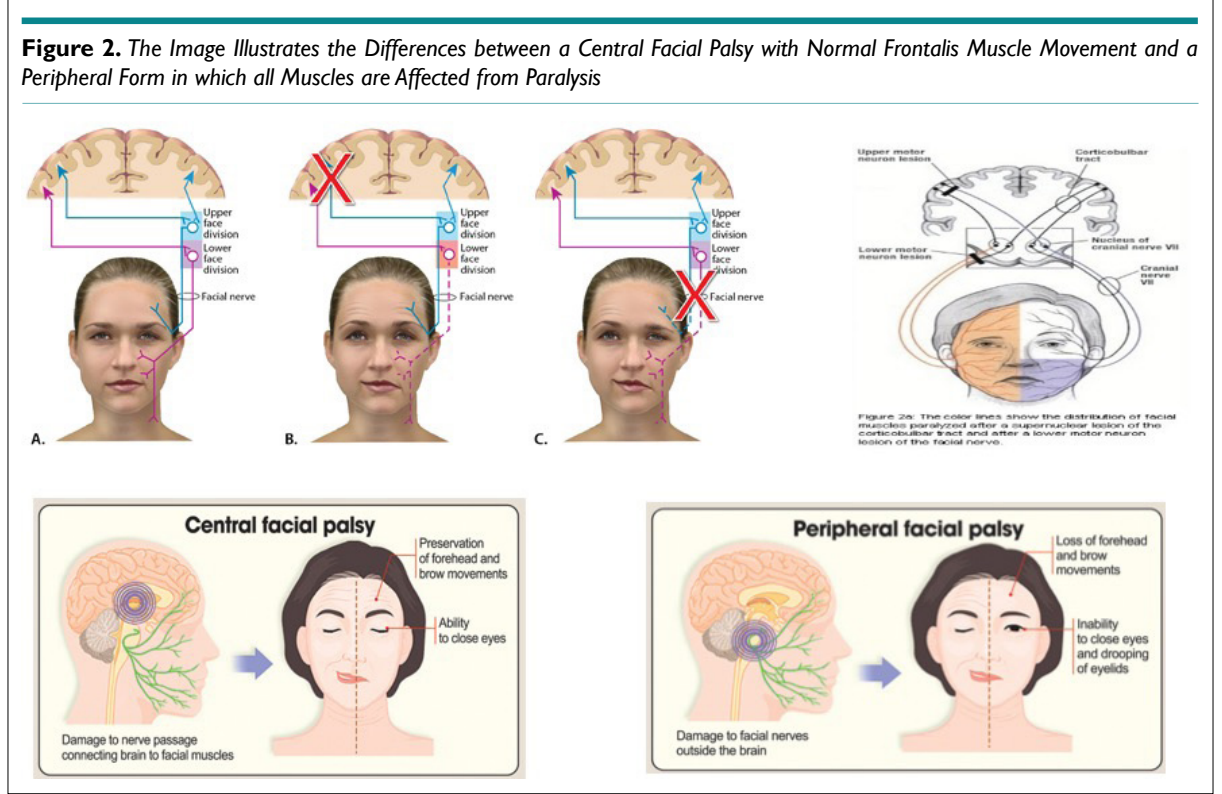

commonly found in the brain and they may migrate in other structures, as for example the inner ear, but they are rarely identified in peripheral nerves when they come out from their bone tract.

The involvement of facial nerve may be plausible in the internal auditory canal (IAC) but an attack of microglia outside this area is very improbable; furthermore, by reviewing the literature none of the authors reported lesion in the IAC in patients affected from FP so, we could deduct that the central lesions only, are responsible for the onset of facial disease.

We may conclude that the central facial pathway is responsible for the manifestations of MS-related facial paralysis.

In our opinion, additional studies are needed to evaluate the prevalence of peripheral versus central involvement in MSrelated facial palsy, and to shed light on its pathophysiology.

\section{CONFLICTS OF INTEREST}

The authors declare that they have no conflicts of interest.

\section{FUNDING}

None.

\section{REFERENCES}

1. Browne P, Chandraratna D, AngoodC, et al. Atlas of Multiple Sclerosis 2013: A growing global problem with widespread inequity. Neurology. 2014; 83(11): 1022-1024. doi: 10.1212/WNL. 0000000000000768

2. Harbo HF, Gold R, Tintoré M. Sex and gender issues in multiple sclerosis. Ther Adv Neurol Disord. 2013; 6(4): 237-248. doi: $10.1177 / 1756285613488434$
3. Luo C, Jian C, Liao Y, et al. The role of microglia in multiple sclerosis. Neuropsychiatr Dis Treat. 2017; 13: 1661-1667. doi: 10.2147/NDT.S140634

4. Di Stadio A, Ralli M. Inner ear involvement in multiple sclerosis: An underestimated condition? Mult Scler. 2018: 1352458518750010. doi: $10.1177 / 1352458518750010$

5. Misawa S, Kuwabara S, Mori M, Hayakawa S, Sawai S, Hattori T. Peripheral nerve demyelination in multiple sclerosis. Clin Neurophysiol.2008; 119(8): 1829-1833. doi: 10.1016/j.clinph.2008.04.010

6. O'Malley JT, Nadol JB Jr, McKenna MJ. Anti CD163+, Iba1+, and CD68+ Cells in the adult human inner ear: Normal distribution of an unappreciated class of macrophages/microglia and implications for inflammatory otopathology in humans. Otol Neurotol. 2016; 37(1): 99-108.

7. Saleh C, Patsi O, Mataigne F, Beyenburg S. Peripheral (Seventh) nerve palsy and multiple sclerosis: A diagnostic dilemma - A case report. Case Rep Neurol. 2016; 8(1): 27-33. doi: 10.1159/000443681

8. Jens W, Ahmed A. Eight and a Half Syndrome from Multiple Sclerosis. J Neurol Stroke. 2015; 3(4): 00099. doi: 10.15406/ jnsk.2015.03.00099

9. Sarigül A, Akça S, Evin B, Singar E, Pınarcı EY. A case of multiple sclerosis presented with $5^{\text {th }}, 6^{\text {th }}$ and $7^{\text {th }}$ cranial nerve paralysis. Turk J Ophthalmol. 2015; 45: 81-83

10. Lassemi E, Sahraian MA, Motamedi MHK, et al. Oral and facial manifestations of patients with multiple sclerosis. Dentistry . 2014; 4: 194. doi: 10.4172/2161-1122.1000194

11. Danesh-Sani SA, Rahimdoost A, Soltani M, Ghiyasi M, Haghdoost N, Sabzali-Zanjankhah S. Clinical assessment of orofacial manifestations in 500 patients with multiple sclerosis. J Oral Maxil- 
lofac Surg. 2013; 71(2): 290-294. doi: 10.1016/j.joms.2012.05.008

12. Lee H, de Kort PLM. 16 Syndrome in a Patient with Multiple Sclerosis. J Neuroophthalmol. 2013; 33(2): 203-204. doi: 10.1097/ WNO.0b013e318284240d

13. Renard D, Poalelungi A, Collombier L, Labauge P. Cranial neuropathies in multiple sclerosis defined by magnetic resonance imaging and fludeoxyglucose $\mathrm{f} 18$ positron emission tomography. Arch Neurol. 2012; 69(4): 541-542. doi: 10.1001/archneurol.2011.1936

14. Uzawa A, Mori M, Ito S, Kuwabara S. Neurological picture. Isolated abducens and facial nerve palsies due to a facial collicular plaque in multiple sclerosis. J Neurol Neurosurg Psychiatry. 2011; 82(1): 85-86. doi: 10.1136/jnnp.2010.206870

15. Ivanković M, Demarin V. From recurrent peripheral facial palsy to multiple sclerosis. Acta Clin Croat. 2011; 50(3): 419-421.

16. Lin Catherine J, Goodman Robert I. Isolated central facial nerve palsy as presentation of multiple sclerosis. Proceedings of UCLA Healthcare. 2010; 14: 1-4.
17. Soltanzadeh A, Sharifi M, Ilkhchoui Y, Sikaroodi H. Isolated facial palsy in Iranian multiple sclerosis patients. Neurology Asia. 2008; 13: 73-75.

18. Kwon JY, Kim JY, Jeong JH, Park KD. Multiple sclerosis and peripheral multifocal demyelinating neuropathies occurring in a same patient. J Clin Neurol. 2008; 4(1): 51-57. doi: 10.3988/ jen.2008.4.1.51

19. Zadro I, Barun B, Habek M, Brinar VV. Isolated cranial nerve palsies in multiple sclerosis. Clin Neurol Neurosurg. 2008; 110(9): 886-888. doi: 10.1016/j.clineuro.2008.02.009

20. Critchley EP. Multiple sclerosis initially presenting as facial palsy. Aviat Space Environ Med. 2004; 75(11): 1001-1004.

21. Thömke F, Lensch E, Ringel K, et al. Isolated cranial nerve palsies in multiple sclerosis. J Neurol Neurosurg Psychiatry. 1997; 63: 682-685. doi: 10.1136/jnnp.63.5.682

22. Fukazawa T, Moriwaka F, Hamada K, Hamada T, Tashiro K. Facial palsy in multiple sclerosis. J Neurol. 1997; 244(10): 631-633. 